\title{
Identification and characterization of N-glycosylation site on a Mucor circinelloides aspartic protease expressed in Pichia pastoris: effect on secretion, activity and thermo-stability
}

\author{
Martin Kangwa ${ }^{* \dagger}$, Jose Antonio Gama Salgado ${ }^{\dagger}$ and Hector Marcelo Fernandez-Lahore ${ }^{\dagger}$
}

\begin{abstract}
Methylotrophic yeasts have widely been used as model organisms for understanding cellular functions and biochemical activities in lower eukaryotes. The gene encoding an aspartic protease (MCAP) from Mucor circinelloides DSM 2183 was cloned and expressed into Pichia pastoris using both the native M. circinelloides signal peptide (mcSP) and a-factor secretion signal from Saccharomyces cerevisiae (a-MF). When expressed in P. pastoris using a-MF and mcSP, MCAP was secreted into the culture medium at a concentration $200 \mathrm{mg} \mathrm{L}^{-1}\left(410 \mathrm{MCU} \mathrm{mL}^{-1}\right)$ and $110 \mathrm{mg} \mathrm{L}^{-1}\left(249 \mathrm{MCU} \mathrm{mL}^{-1}\right)$, respectively. The SDS-PAGE analysis of each culture shows that the protein was secreted in the media in two forms with molecular weights of approximately 33 and $37 \mathrm{kDa}$. Upon digestion using endoglycosidase $\mathrm{H}(\mathrm{Endo} \mathrm{H}$ ), only one band at $33 \mathrm{kDa}$ was observed, indicating that the protein might be glycosylated. One putative N-glycosylation site was found and a site-directed mutagenesis at position Asn331-Gln of the sequence produce only one form of the protein of $33 \mathrm{kDa}$, similar to that obtained when digested with Endo $\mathrm{H}$. The optimum temperature and $\mathrm{pH}$ activity of the expressed MCAP was found to be at $60^{\circ} \mathrm{C}$ and 3.6 , respectively.
\end{abstract}

Keywords: Aspartic proteinase, Mucor circinelloides, Secretion signal peptide, Pichia pastoris, milk-clotting unit (MCU), N-glycosylation

\section{Introduction}

Methylotrophic yeast, mainly Pichia pastoris have emerged as an attractive industrial strain for the production of viable proteins (Yang et al. 2015; Daly and Hearn 2005), as they are considered to possess several advantages, including low cost and large-scale production, easy to scale-up, harvesting, and storage. They are able to produce high yields of secreted biologically active valuable recombinant proteins (Daly and Hearn 2005; Dietzsch et al. 2011). One of the principal advantages of yeast production systems is their ability to perform the post-translational modification, which is required for glycosylation,

\footnotetext{
*Correspondence: m.kangwa@jacobs-university.de;

m.fernandez-lahore@jacobs-university.de

†Martin Kangwa, Jose Antonio Gama Salgado and Hector Marcelo Fernandez-Lahore contributed equally to this work

Downstream Bioprocessing Laboratory, Department of Life Sciences \& Chemistry, Jacobs University, Campus Ring 1, 28759 Bremen, Germany
}

phosphorylation, and methylation, as well as proteolytic processing and non-enzymatic modifications for biological activity and stability (Spadiut and Herwig 2014; Dietzsch et al. 2011; Walsh and Jefferis 2006).

The attachment of sugar molecules to protein is one of the most well-known and vital forms of co- and post-translational modification as the addition can significantly change the structure, and subsequently the function of the protein. The addition of sugar residues can occur at certain amino acid side-chains, and these modifications can be $\mathrm{N}$ - and $\mathrm{O}$-glycosylation type, phosphoglycation, C-mannosylation, and glypiation (Fitchette-Lainé et al. 1998; Spiro 2002). P. pastoris is known to $\mathrm{N}$-glycosylate proteins via mannose oligosaccharide linked to asparagine via its two $\mathrm{N}$-acetylglucosamines and these diverse roles of glycans can affect the conformational maturation, secretion, activity, and stability of glycoproteins (Laukens et al. 2015; Yang et al. 2015). 
This modification can either be advantageous or not depending on the application field of the desired protein. Detailed studies on deglycosylation conducted on aspartic proteinase of Mucor pusillus have revealed that the elimination of $\mathrm{N}$-linked carbohydrate groups from the protein affects the enzyme properties such as milk-clotting and proteolytic activities while leading to a decrease in the level of secretion and thermal stability in other fungi (Aikawa et al. 1990; Yamashita et al. 1994). Moreover, a high degree of glycosylation has been proposed to be the purpose for a well-stabilized structural conformation, which may confer a high level of thermal stability for the aspartic proteinase from Rhizomucor miehei (Celebi et al. 2016; Soltani et al. 2016), M. pusillus, Sporisorium reilianum and A. niger (Mandujano-González et al. 2016; Rickert and McBride-Warren 1977; Zhang et al. 2015).

Aspartic proteinases (APs; EC.3.4.23.-) also known as acid proteases are a significant group of enzymes, produced by a variety of organisms including plants and animals, mainly used as milk coagulating agents in industrial cheese production (Yegin and Dekker 2013; Hsiao et al. 2014). Rennet, a milk coagulant obtained from the abomasum of milk-fed lambs and calves, is regarded as the industrial gold standard in cheese manufacturing (Kethireddipalli and Hill 2015). Chymosin (EC 3.4.23.4) is the main milk-clotting component of natural rennet with activity amounting to about $90 \%$ of the total observed potency (Salehi et al. 2017; Kumar et al. 2010). Chymosin specifically cleaves the $\mathrm{Phe}_{105}-\mathrm{Met}_{106}$ bond of $\mathrm{K}$-casein $(\kappa-\mathrm{CN})$ resulting in the formation of the (hydrophobic) para- $\mathrm{k}$-casein and the (hydrophilic) biologically active component glycomacropeptide (Neelima et al. 2013). The glycomacropeptide further diffuses into cheese whey and the destabilized micelles consequently aggregate to form cheese curd via the $\mathrm{Ca}^{2+}$ induced aggregation (Hang et al. 2016; El-Baky et al. 2011). Due to increased demand for cheese products, animal-derived milk coagulants are not enough to cover the production, and this has prompted research efforts in the search, manufacture of recombinant and microbial rennin. Substitutes with milk coagulating ability must present some of calf rennet specific properties like a high ratio of milk clotting activity and suitable thermal stability. Microbial milk coagulants, also known as mucor rennins produced by microorganisms like Rhizomucor miehei (Gray et al. 1986; Ottesen and Rickert 1970), Rhizomucor pusillus (Arima et al. 1968; Tonouchi et al. 1986), and Endothia parasitica have found extensive application as milk coagulating enzymes in industrial cheese production (Jacob et al. 2011; Nasr et al. 2016). However, these fungal enzymes have several disadvantages when compared to their animal counterpart rennet, due to the flavour and bitter taste that dominate the cheese products; produced especially after a long period of maturation. For this reason, researchers have focused on finding new enzymes that possess the desired properties and characteristics dearly needed in cheese manufacturing. With this goal in focus, aspartic proteinase was isolated from $M$. circinelloides and further characterized.

In our previous studies, the aspartic protease gene from M. circinelloides (GenBank accession no. JQ906105 and JQ906106) was cloned and expressed in P. pastoris (Gama Salgado et al. 2013). In this, present work, an M. circinelloides aspartic proteinase (MCAP), GenBank accession no. JQ906105 and JQ906106 with its native signal peptide (mcSP) were successfully expressed in $P$. pastoris. We further focused on identifying and analyzing the $\mathrm{N}$-glycosylation site of an $M$. circinelloides aspartic protease and analyzing its effect on secretion, activity, and thermostability.

\section{Materials and methods}

\section{Fungal, bacterial strains, and media}

Escherichia coli Top10 strain (Invitrogen, Darmstadt, Germany), (Table 1) was used for all cloning procedures and grown with shaking at $220 \mathrm{rpm}$ at $37^{\circ} \mathrm{C}$ in LuriaBertani medium $\left(5 \mathrm{~g} \mathrm{~L}^{-1}\right.$ yeast extract, $10 \mathrm{~g} \mathrm{~L}^{-1}$ tryptone, $5 \mathrm{~g} \mathrm{~L}^{-1} \mathrm{NaCl}$ ). Recombinant $P$. pastoris, was screened on YPDS agar plates $\left(20 \mathrm{~g} \mathrm{~L}^{-1}\right.$ peptone, $10 \mathrm{~g} \mathrm{~L}^{-1}$ yeast extract, $40 \mathrm{~g} \mathrm{~L}^{-1}$ glucose, $1 \mathrm{M}$ sorbitol and $2 \%$ agar) containing $100 \mu \mathrm{g} \mathrm{mL}{ }^{-1}$ of Zeocin (Invitrogen, Darmstadt, Germany). Pichia pastoris X-33 and SMD1168 strains (Invitrogen, Darmstadt, Germany), were used as platform strains for all engineered $P$. pastoris, and were grown at $24{ }^{\circ} \mathrm{C}$ for $72 \mathrm{~h}$ in $250 \mathrm{~mL}$ shake flask containing $75 \mathrm{~mL}$ of YPD liquid media ( $20 \mathrm{~g} \mathrm{~L}^{-1}$ peptone, $10 \mathrm{~g} \mathrm{~L}^{-1}$ yeast extract, $40 \mathrm{~g} \mathrm{~L}^{-1}$ glucose, $\mathrm{pH}$ : 5.0 adjusted with citric acid) in a shaking incubator at $250 \mathrm{rpm}$. All components for media preparation were purchased from Carl Roth GmbH, Germany. Media, electro-competent E.coli and $P$. pastoris cells were prepared according to the Expression kit manual (Invitrogen).

\section{DNA manipulations, primers, and DNA sequencing}

Taq DNA polymerase, T4 DNA ligase and restriction enzymes were purchased from New England Biolabs (NEB), while $P f u$ Ultra High Fidelity DNA Polymerase was from Stratagene, Heidelberg, Germany. All enzymes were used as specified by the manufacturer, plasmids were extracted using a QIAprep Spin Miniprep Kit, while the PCR products were purified using the QIAquick PCR Purification Kit (QIAGEN, Hilden, Germany). The synthesis of primers and nucleotides sequencings used in this study was performed by Eurofins MWG Operon (Eurofins MWG Operon, Ebersberg, Germany). 
Table 1 Microorganisms and plasmids used in this study

\begin{tabular}{|c|c|c|}
\hline Strain or plasmid & Genotype & Source or references \\
\hline \multicolumn{3}{|l|}{ Escherichia coli } \\
\hline Top10 & $\begin{array}{l}\text { F- mcrA } \triangle \text { (mrr-hsdRMS-mcrBC) } \varphi 80 \text { lacZ } \triangle \text { M15 } \triangle \text { lacX74 recA1 araD139 } \triangle \text { (ara-leu) } \\
7697 \text { galU galK rpsL (StrR) endA1 nupG }\end{array}$ & Invitrogen \\
\hline \multicolumn{3}{|l|}{ Pichia pastoris } \\
\hline$x-33$ & Wild type & Invitrogen \\
\hline SMD1168 & Protease deficient & Invitrogen \\
\hline \multicolumn{3}{|l|}{ Plasmids } \\
\hline pGAPZa-A & $\begin{array}{l}\text { The pGAPZa-A vector uses the GAP promoter to constitutively express recombi- } \\
\text { nant proteins in Pichia pastoris }\end{array}$ & Invitrogen \\
\hline pGAM1 & $\begin{array}{l}\text { A pGAPZa-A derived vector where the a-MF is replaced by mcSP and uses the } \\
\text { GAP promoter to constitutively express recombinant proteins in Pichia pastoris }\end{array}$ & This work \\
\hline pGAPZa + MCAP-5 & $\begin{array}{l}\text { PGAPZa-A derivative carrying the MCAP gene without a signal sequence and } \\
\text { without introns }{ }^{\mathrm{a}}\end{array}$ & Gama Salgado et al. (2013) \\
\hline pGAM1 + MCAP-3 & $\begin{array}{l}\text { pGAPZa-A + MCAP-3 derivative carrying the MCAP with mcSF without an } \\
\text { intron }^{b}\end{array}$ & This work \\
\hline pGAM1 + MutMCAP-8 & $\begin{array}{l}\text { pGAPZa-A + MCAP-3 derivative is carrying the MCAP without an intron. The } \\
\text { codon of the amino acid asparagine } 331 \text { (AAC) was changed to Glutamine } \\
(\text { CAA })^{b}\end{array}$ & This work (Single mutant Asn331-Gln) \\
\hline pGAM1 + SyMCAP-6 & $\begin{array}{l}\text { PGAM1 + SyMCAP-6 derivative carrying the MCAP gene with native signal } \\
\text { sequence and without intron. The original MCAP gene was adapted to the } \\
\text { optimal codon usage of P. pastoris. The insert was Cloned flush with the Kex } 2 \\
\text { cleavage site and in frame of the native signal sequence and in frame with the } \\
\text { C-terminal polyhistidine tag into the Xhol and Not/ site of the PGAM1 }\end{array}$ & Gama Salgado et al. (2013) and in this work \\
\hline
\end{tabular}

The PCR protocol for the construction of plasmids and for the identification of recombinant strains was a follow; $1 \times$ ThermoPol reaction buffer, $200 \mu \mathrm{mol} \mu \mathrm{L}^{-1} \mathrm{dNTPs}$, $2 \mathrm{pmol} \mu \mathrm{L}^{-1}$ of each primer (forward and reverse), 0.6-1 ng $\mu \mathrm{L}^{-1}$ plasmid DNA, 0.04 units $\mu \mathrm{L}^{-1} \mathrm{Taq}$ DNA polymerase final concentration. PCR reactions were carried in a total volume of $50 \mu \mathrm{L}$ using a Mastercycler ep gradient S (Eppendorf, Hamburg, Germany).

\section{Plasmids construction}

The plasmids used in this study can be found in Table 1 . Expression vector pGAM1 + MCAP-3, containing the $M C A P$ coding sequence with its native signal peptide sequence, was constructed as follows: the gene encoding M. circinelloides aspartic proteinase with its native $m c S P$ sequence was PCR amplified using primer sequences MCAP-Fw 5'-TAT CTC GAG AAA AGA ATG AAA TTC TCA TTA GTC TCT TCT TGT G- $3^{\prime}$ and MCAPRv 5'-TGG CGG CCG CGA CAG ATT TGG CAA TTT GGA $C-3^{\prime}$ having restriction site XhoI and NotI site, respectively, producing the insert product $m c S P-M C A P$. PCR amplification was done using the $P f u$ Ultra High Fidelity DNA Polymerase (Stratagene, Heidelberg, Germany) consisting of 36 cycles of $94{ }^{\circ} \mathrm{C}$ for $30 \mathrm{~s}, 60^{\circ} \mathrm{C}$ for $40 \mathrm{~s}$ and $68^{\circ} \mathrm{C}$ for $2 \mathrm{~min}$, and followed by a final extension step at $68^{\circ} \mathrm{C}$ for $10 \mathrm{~min}$, producing PCR gene product of about $1211 \mathrm{bp}$. After PCR the product was purified and digested using the enzyme XhoI and NotI. The vector backbone was digested and later ligated with the digested $m c S P-M C A P$ and the resulting plasmid was the designated pGAM1 + MCAP-3, with the $6 x \mathrm{His}$ tag at the Cterminal and the bleo gene as a selectable marker.

\section{Site-directed mutagenesis on $\mathrm{N}$-glycosylation site sequence}

Mutations on the glycosylation site were generated by a point mutation using the plasmid pGAM1 + MCAP-3 as the template. The codon for $\mathrm{N}$ (Asn331) in the glycosylation sequon was replaced with Q $(G l n)$ to eliminate the $\mathrm{N}$-glycosylation site using 5'-AAG CCT CTT cag TTC ACC ATC AAC GGT-3' as the sense oligonucleotides to generate the mutant plasmid pGAM1+MutMCAP-8. The plasmid was transformed into $E$. coli. The presence of the mutation was verified by nucleotide sequencing.

\section{E. coli and P. pastoris transformation}

The plasmids were transformed into E. coli TOP10 competent cells and the cells were screened on Luria-Bertani plates containing $40 \mu \mathrm{g} \mathrm{mL}{ }^{-1}$ of zeocin. Plasmids were isolated from overnight cultures of positive colonies and 
were sequenced for the insert of interest to confirm the correctness of the nucleotide sequence. Plasmids carrying $M C A P$ coding sequence were digested with AvrII restriction enzyme and further transformed into either $P$. pastoris X-33 or SMD1168 using a Multiporator (Eppendorf, Hamburg, Germany), according to the supplier's protocol. Transformants carrying MCAP coding sequence was identified by PCR amplification using the primers pGAP-Fw 5'-GTCCCTATTTCAATCAATTGA ACAAC-3' and AOX1-pGAP-Rv 5'-CAAATGGCATTC TGACATCCTC- $3^{\prime}$ and by sequencing. The PCR amplification was carried out at an annealing temperature of $58{ }^{\circ} \mathrm{C}$ for 29 cycles.

\section{MCAP production and milk clotting activity assay}

To produce MCAPs in P. pastoris, single colonies of positive transformants were cultured in $25 \mathrm{~mL}$ YPD media in a $100 \mathrm{~mL}$ shake flasks for $20 \mathrm{~h}$ at $24{ }^{\circ} \mathrm{C}$ as a starter culture and further used to inoculate $75 \mathrm{~mL}$ of YPD medium in $250 \mathrm{~mL}$ shake flasks in triplicate with a starting $\mathrm{OD}_{600}$ of 0.1. Cultivation was conducted for 3 days. The culture was centrifuged to obtain the crude protein extracts, later desalted using the PD-10 column equilibrated with $20 \mathrm{mM} \mathrm{KH}_{2} \mathrm{PO}_{4}$ buffer, at $\mathrm{pH}$ 6.0. When required, recombinant MCAP were deglycosylated by endoglycosidase $\mathrm{H}$ under the conditions specified by the enzyme manufacturer (New England Biolabs, Germany). Milk-clotting activity from the extracts was determined according to the method by Arima et al. (1968), with some modifications (Gama Salgado et al. 2013). Primarily, $1 \mathrm{~mL}$ of a substrate made of $100 \mathrm{~g} \mathrm{~L}^{-1}$ powder skimmed milk and $10 \mathrm{mM} \mathrm{CaCl}$ in sterile distilled water was added to a final volume of $10 \mathrm{~mL}$ and incubated at $35^{\circ} \mathrm{C}$ for $10 \mathrm{~min}$. Next, $0.1 \mathrm{~mL}$ of enzyme sample was added to the preincubated substrate. One milk clotting unit (MCU) is defined as the amount of enzyme which clotted $1 \mathrm{~mL}$ of the substrate in $40 \mathrm{~min}$ at $35^{\circ} \mathrm{C}$ (Arima et al. 1968; Rao et al. 2011). Based on this definition, the milk clotting activity was calculated based on the equation of Rao and coworker (Rao et al. 2011), (Eq. 1).

$$
\mathrm{MCU} \mathrm{mL}{ }^{-1}=2400 /(\mathrm{t} \cdot \mathrm{E})
$$

In which 2400 is the conversion of $40 \mathrm{~min}$ to sec, t; clotting time (s) while E; the enzyme volume (mL).

\section{Purification of MCAP}

All purification experiments were conducted using an ÄKTA purifier system (GE Healthcare, Munich, Germany). Upon removal of the cells debris by centrifugation at $4000 g, 4{ }^{\circ} \mathrm{C}$, the MCAP recombinant proteins were purified by cation-exchange chromatography utilizing a $5 \mathrm{~mL}$ HiTrap SP FF column mounted to the ÄKTA purifier. Protein extracts were adjusted to $\mathrm{pH} 3.1$ utilizing citric acid, and then $37-48 \mathrm{~mL}$ of the sample mixture was injected to the previously equilibrated column $(75 \mathrm{mM}$ $\mathrm{NaCl}$ and $50 \mathrm{mM}$ citric acid at $\mathrm{pH} 3.5$ ). After washing with the same buffer, step gradient elution in 5 column

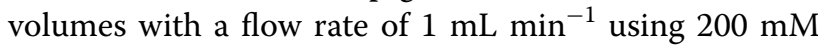
$\mathrm{NaCl}$ and $50 \mathrm{mM}$ citric acid at $\mathrm{pH} 3.5$ was conducted. Purified fractions were collected and analyzed for protein content and milk clotting assays.

\section{Deglycosylation assay}

Crude extracellular protein amounting to $35 \mu \mathrm{g}$, previously desalted using an equilibrated $\left(20 \mathrm{mM} \mathrm{KH_{2 }} \mathrm{PO}_{4}\right.$ buffer, pH 6.0) PD-10 column was digested with 2 units of endo $\mathrm{H}$ (New England Biolabs, Frankfurt, Germany) at $37^{\circ} \mathrm{C}$ for $2 \mathrm{~h}$.

\section{Protein determination}

Protein content in the crude extract, supernatant broth, as well in the chromatographic fractions was determined as per Bradford procedure (Bradford 1976) and bovine serum albumin was used as a standard (Fischer Scientific, Schwerte, Germany).

\section{SDS-PAGE analysis}

After separation of $P$. pastoris transformants culture by centrifugation, the supernatant proteins were desalted utilizing a PD-10 column (GE Healthcare, Munich, Germany) equilibrated with $20 \mathrm{mM} \mathrm{KH_{2 }} \mathrm{PO}_{4}$ buffer at $\mathrm{pH}$ 7.2. When needed, the crude protein was concentrated at room temperature using Vacuum Concentrator 5305 (Eppendorf, Hamburg, Germany) and loaded on a $12.5 \%$ SDS-polyacrylamide gel electrophoresis. The crude authentic MCAP (control) produced by $M$. circinelloides and purified MCAP were also loaded directly on the SDS-PAGE gel for electrophoresis and was stained in Coomassie brilliant blue solution.

\section{Thermostability of the recombinant enzymes}

The purified protein thermostability was determined by incubating the enzyme samples at temperature values between $35{ }^{\circ} \mathrm{C}$ to $65{ }^{\circ} \mathrm{C}$ for $10 \mathrm{~min}$. After incubation for $10 \mathrm{~min}$, samples were chilled in an ice bath prior to assay for analyzing of residual milk-clotting activity.

\section{Proteolytic activity assay}

The obtained chromatographic fractions were further used for proteolytic activities (PA) analysis based on the method by Fan and coworkers using N, N-dimethyl casein (DCM) as the substrate (Fan et al. 2010). For the sample analysis, $10 \mathrm{mg}$ of DCM was dissolved in $1 \mathrm{~mL}$ of $20 \mathrm{mM}$ phosphate buffer, $\mathrm{pH}$ 5.8. Subsequently, $45 \mu \mathrm{L}$ of enzyme sample was thoroughly mixed with $45 \mu \mathrm{L}$ of the solution and incubated at $35{ }^{\circ} \mathrm{C}$ for $30 \mathrm{~min}$. To end 
the reaction, $1.35 \mathrm{~mL}$ of $10 \%$ ice-cold trichloroacetic acid (TCA) was used and the samples were kept on ice for $30 \mathrm{~min}$. The samples were later centrifuged at $15,000 \mathrm{~g}$ for $15 \mathrm{~min}$ and the absorbance of the mixture was measured at $280 \mathrm{~nm}$. For the reference solution, TCA was added before the enzyme. One unit of proteolytic activity ( $U$ $\left.\mathrm{mL}^{-1}\right)$ is defined as the quantity in microgram of tyrosine released from $\mathrm{DCM}$ per minute at $35{ }^{\circ} \mathrm{C}$. The extinction of tyrosine was taken to be $0.005 \mathrm{~mL} \mathrm{\mu g}^{-1} \mathrm{~cm}$, (Eq. 2).

$$
\begin{aligned}
\mathrm{PA}((\mathrm{U} / \mathrm{mL}) & =\left(\mathrm{A}_{280 \mathrm{~nm} / 0.005)}\right. \\
& \times 1.44 \mathrm{~V} \times(1 / 30) \times 1000 / 45)
\end{aligned}
$$

where $\mathrm{V}$ is a volume in $\mathrm{mL}$.

\section{Results}

\section{Sequence analysis of the Signal peptide of MCAP (mcSP)}

Most proteins that are secreted by organisms possess a signal peptide sequence, which is cleaved by signal peptidase (SPase) upon maturation (Blobel 2000). In particular, all the fungal aspartic proteases sequences reported so far have a signal peptide. In our studies, the gene that encodes the MCAP protein was PCR amplified from a fungal plant pathogen strain $M$. circinelloides DSM 2183 and a 1229 bp including one intron of 63 bp long fragment (Fig. 1a, b, Additional file 1:
Table S1) was obtained. It consists of a signal peptide (SP) and the fragment showed the presence of catalytic Asp residues commonly found in most known aspartic proteinases. The catalytic Asp residues are usually found within the motif Asp-Xaa-Gly where Xaa can either be Ser or Thr (Rao et al. 2011). Additionally, the SP was predicted using the SignalP 4.0 server (Center for Biological Sequence Analysis, Technical University of Denmark, DTU) that recognized a cleavage signal sequence site to be between the amino acid positions Ala-21 and Ala-22 (Fig. 1c). According to the deduced amino acid sequence, MCAP has a putative pre-pro region of 72 amino acid (aa) residues, preceded by the mature enzyme of 322 aa. The $M$. circinelloides signal peptide (mcSP) corresponding to the first 21 aa (MKFSLVSSCVALVVMTLAVDA) shows typical features for targeting a protein to the membrane, such as a highly hydrophobic region and a pro-enzyme sequence consisting of about 51 aa (Gama Salgado et al. 2013).

In this study protein secretion using the native mcSP was analyzed and it was found that the MCAP was secreted into the culture medium at a concentration $200 \mathrm{mg} \mathrm{L}^{-1}$ while MCAP with an $\alpha-\mathrm{MF}$ was at $110 \mathrm{mg} \mathrm{L}^{-1}$, respectively, after three days of cultivation. From the data obtained, it was observed that the

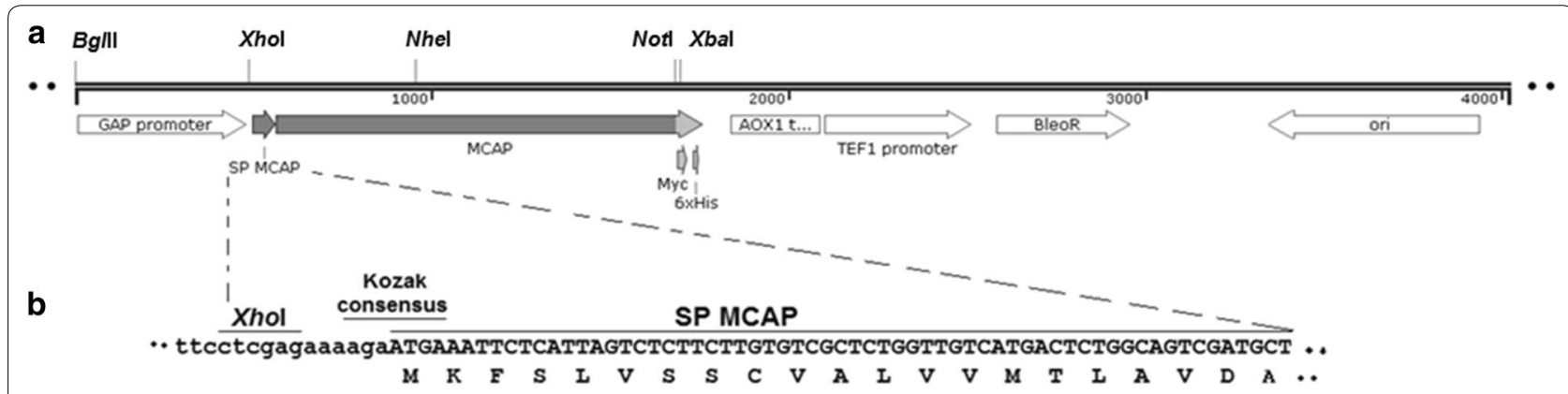

C

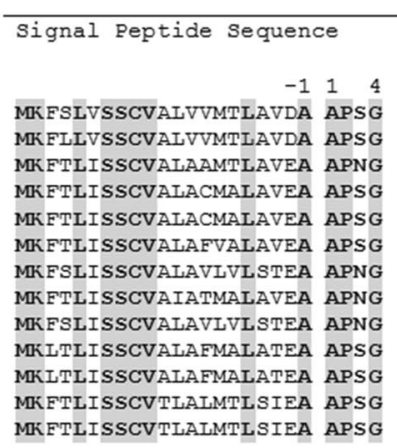

$\begin{gathered}\text { Identitie } \\ (8)=\end{gathered}$
-
968
768
768
768
728
688
688
688
688
688
688
688

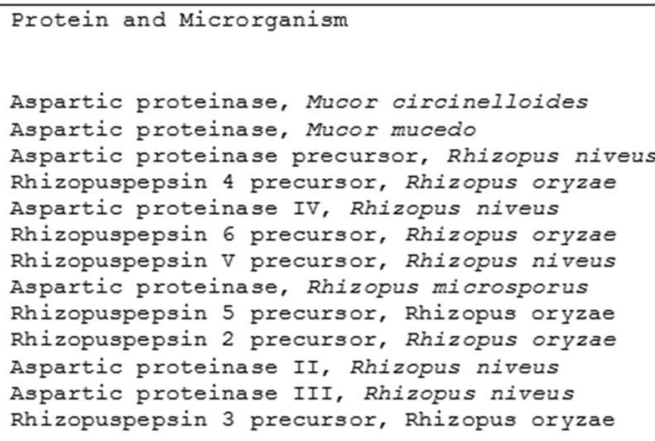

Accession number

GenBank : AFJ12376 GenBank : AFB3565 4

GenBank : A.A.A33882 GenBank : ACL68091 GenBank : CAA40309 GenBank : ACL 68087 PIR: $S 29550$

GenBank : CA.A72511

GenBank : ACL 68092 GenBank : ACL 68089 GenBank : CAA40284 GenBank : CAA4 0285 GenBank : ACL 68090

Fig. 1 Recombinant plasmid construction pGAM1 + MCAP-3: a map of pGAM1 + MCAP-3, b diagram of the MCAP gene showing the Kozak consensus located between the GAP promoter and the SP MCAP sequence of PGAM1 + MCAP-3. c The identity of the signal peptide sequence (SP MCAP) of M. circinelloides with other fungal counterparts. The residues are numbered according to the signal sequence cleavage (between position -1 and 1: A-AP). The residues identical are shaded in grey 
strain containing the $M C A P$ cloned downstream of the $\alpha$-factor signal sequence produced an enzyme with 249 $\mathrm{U}$ (Milk clotting units $\mathrm{mL}^{-1}$ ), while recombinants $\mathrm{X}-33$ / pGAM1+MCAP-3 and SMD116/pGAM1+MCAP-3 carrying the mcSP expressed $410 \mathrm{U}$ and $415 \mathrm{U}$, respectively. The MCAP protein produced by the recombinant yeast (X-33/pGAM1 + MCAP-3 and SMD116/ pGAM1 + MCAP-3) was estimated to be $200 \mathrm{mg} \mathrm{L}^{-1}$ and Table 2 summarizes the expression levels between mcSP and $\alpha$-factor signal.

The lower amount of protein with the $\alpha$-MF fused could be due to the difference in the processing level of the $\alpha$-MF and mcSP prepropeptides, or different levels of gene expression and stability, of which a further study in which fusing different protein varieties will be thoroughly implemented. The obtained results indicate that the mcSP is effective for protein secretion in yeast cells and can be used as an alternative to the alpha-factor SP mainly used in yeast protein secretion.

\section{Protein expression and analysis of the $\mathrm{N}$-glycosylation sites by site-directed mutagenesis}

Previously it was reported that $P$. pastoris, carrying the plasmid pGAPZ $\alpha A+$ MCAP-5 produced two forms of extracellular MCAP: glycosylated and non-glycosylated and a further digestion of the MCAP with endoglycosidase $H$ caused a decrease in the superficial molecular weight (Gama Salgado et al. 2013). Therefore, yeast strain X-33/pGAPZ $\alpha+$ MCAP-5, X-33/wildtype, X-33/ pGAM1 + MCAP-3 were cultured in YPD medium consisting of $4 \%$ glucose at $24{ }^{\circ} \mathrm{C}$ for 3 days at $\mathrm{pH} 5.0$ and Fig. 2a shows an SDS-PAGE gel of the extracellular extract with arrows indicating the expressed types of MCAP protein ( $G$ and N, Glycosylated and Non-glycosylated, respectively). Furthermore, enzymatic analysis of the extracellular extract from X-33/pGAM1 + MCAP-3 with endoglycosidase (Endo $\mathrm{H}$ ) showed a decrease in the molecular weight $(33 \mathrm{kDa})$ indicating that the protein

Table 2 Expression and activity analysis between mcSPMCAP and $a-M F-M C A P$

\begin{tabular}{lllc}
\hline Strain & Signal peptide & $\begin{array}{l}\text { Crude } \\
\text { extract } \\
\left(\mathbf{m g ~ L}^{-1}\right)\end{array}$ & $\begin{array}{l}\text { Milk clotting } \\
\left.\text { (units } \mathbf{~ m}^{-1}\right)\end{array}$ \\
\hline X-33/Wild-type & - & 0 & 0 \\
X-33/MCAP3 & a-MF+mcSP & 0 & 0 \\
X-33/MCAP-5 & a-MF & 110 & 249 \\
X-33/MCAP-3 & mcSP & 200 & 410 \\
SMD1168/MCAP-3 & mCSP & 200 & 415
\end{tabular}

Date are given as average, $n=3$ was initially expressed in the glycosylated form (Fig. 2b, lane 2).

By using NetNGlyc v1.0. Software, one potential N-glycosylation site (Asn-X-Ser/Thr) was found to be located at positions Asn331 and any possible O-glycosylation sites were also predicted by NetOGlyc v3.1. Therefore, to show and proof the presence of $\mathrm{N}$-glycosylation sites on aspartic proteinase of $M$. circinelloides produced in $P$. pastoris, a mutant where $\mathrm{N}$ (Asn331) was replaced with $\mathrm{Q}$ (Gln) was created by site-directed mutagenesis and was successfully expressed in P. pastoris. The cultivation of the mutant and non-mutants (Table 3) was carried as described in "Materials and methods" section. After cultivation, the cells were separated from the medium and the supernatants were analyzed by SDS-PAGE. From the SDS-PAGE analysis (Fig. 3a), it can be seen that the recombinants in lane 4 expressed a single MCAP protein having a molecular weight of almost $33 \mathrm{kDa}$ compared to lane 2 and 3, where two bands where observed. From these results, we can conclude that the protein was glycosylated at the Asn331 position. The mutant protein Asn331-Gln and the wild-type protein were further deglycosylated with Endo H. We can see from Fig. 3b lane 1 and 2 that upon deglycosylation, the protein molecular weight of almost $33 \mathrm{kDa}$ was seen for both, a band of the molecular weight similar that of line 4 in Fig. 3a. From these results, we can confirm that native MCAP is produced in both unglycosylated and glycosylated form.

\section{Optimum pH}

To further analyze the $\mathrm{pH}$ stability of the MCAP, the enzyme preparations were initially incubated at $30{ }^{\circ} \mathrm{C}$ for $1 \mathrm{~h}$ in $20 \mathrm{mM}$ citric acid buffers within a $\mathrm{pH}$ range of 3.3 and 3.8. Figure 4 shows that the maximum enzyme activity for both mutated and non-mutated was at pH 3.6. Previous results showed that MCAP enzyme was stable between $\mathrm{pH} 3.0$ and 4.0, though at a $\mathrm{pH}$ of 7.0 the activity decreased drastically. Fernandez- Lahore et al. reported a similar behaviour of an acid proteinase from mesophilic Mucor sp. were it was also found that MCAP enzyme is not stable under the same conditions above a $\mathrm{pH}$ of 7.5 (Fernandez-Lahore et al. 1999).

\section{Optimum temperature and thermostability of MCAP enzymes}

The MCAP enzyme activity was determined as a function of temperature from 35 to $65^{\circ} \mathrm{C}$ and Fig. 5a shows that the highest enzyme activity was at $60{ }^{\circ} \mathrm{C}$ irrespective of the type of protein. In specific instances, upon $60 \mathrm{~min}$ incubation period enzyme activity begins to decrease at a temperature above of $50{ }^{\circ} \mathrm{C}$. When unpurified MCAP's where tested, it was found that after 60 min of incubation at $55{ }^{\circ} \mathrm{C}, 75 \%$ of enzyme activity was retained (Fig. 5b) 


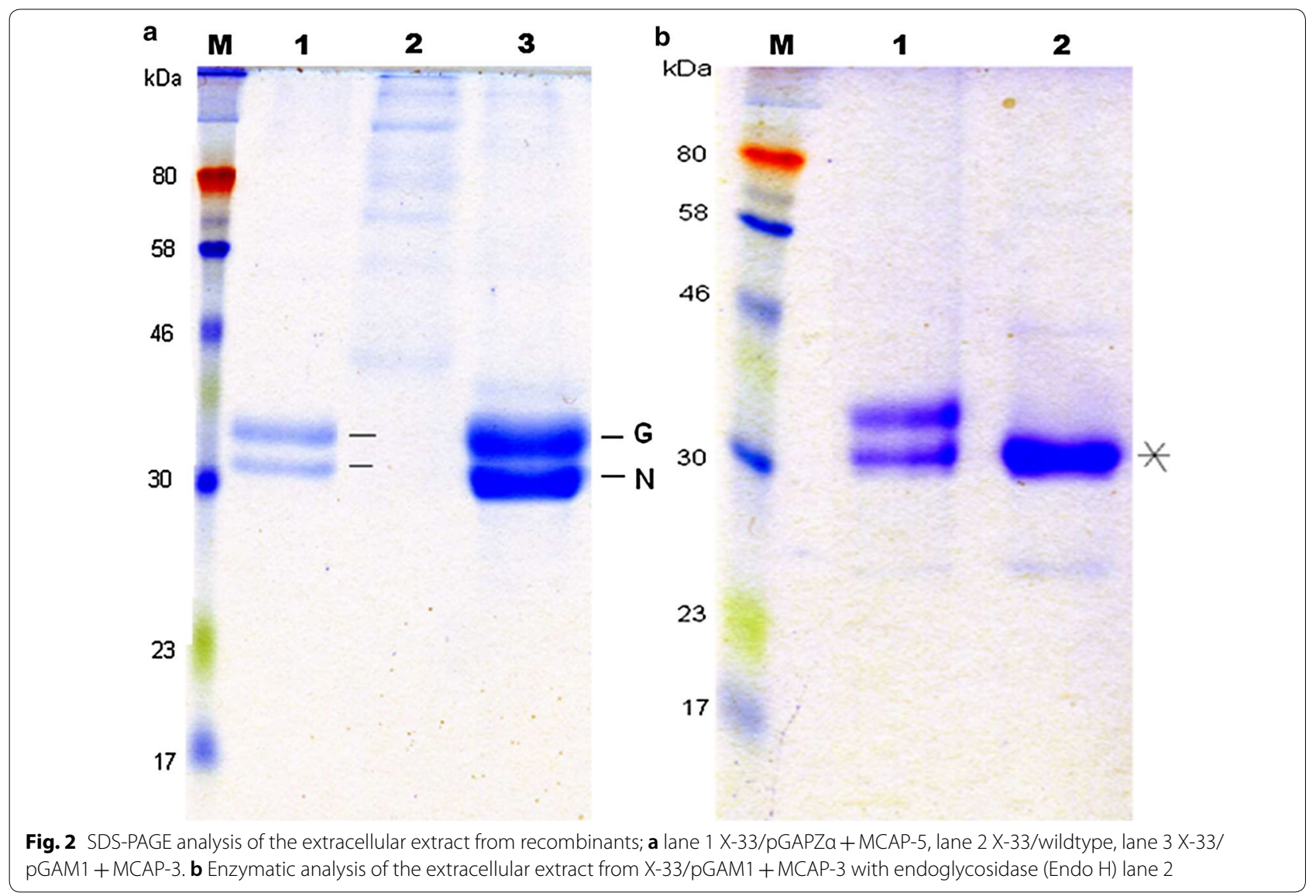

Table 3 Summary of production and purification of MCAP

\begin{tabular}{llllll}
\hline Sample & Step & Volume $(\mathbf{m L})$ & Protein ${ }^{\mathbf{a}}(\mathbf{m g})$ & Recovery (\%) & $\begin{array}{l}\text { Purification } \\
\text { (fold) }\end{array}$ \\
\hline MCAP-3 (non-mutated) & Crude & 49 & 8.44 & 100 & 1 \\
& IEX & 12.5 & 4.67 & 55.3 & 2.1 \\
SyMCAP-6 (synthetic) & Crude & 50 & 14 & 100 & 1 \\
& IEX & 12.5 & 9.17 & 65.5 & 1.5 \\
MutMCAP-8 (mutated) & Crude & 48 & $\underline{5.76}$ & 100 & 1 \\
& IEX & 7.5 & 3.5 & 60.7 & 6.6
\end{tabular}

a Date are given as average, $n=3$

and $40-60 \%$ of the enzyme activity at $60^{\circ} \mathrm{C}$ (Fig. 5c) upon a $60 \mathrm{~min}$ incubation period at $\mathrm{pH} 3.6$. As indicated in Fig. $5 \mathrm{~d}$, the retained activity of the purified MCAP varies considerably to the non-purified protein. Results also showed that there was less or no effect of glycosylation on the thermostability of the purified enzymes (Fig. 5d). From the results, it can be noted that a difference exists between crude and the purified samples on the point of thermal stability. This might be due to other elements in the culture medium that might affect protein integrity. Though, from the SDS-PAGE pattern of the crude enzyme samples obtained in this study (Fig. 3), we can clearly see that the aspartic protease produced in $P$. pastoris is the main protein in the culture supernatant. Generally, enzyme thermostability is an inherent property, determined mainly by the protein primary structure. However, external factors like cations, substrates, co-enzymes, modulators and other proteins often affect enzyme thermostability.

The vicinity of $\mathrm{N}$-glycosylation site to the catalytic site may also have a potential effect on thermal and biochemical parameters of the enzyme, therefore possible 


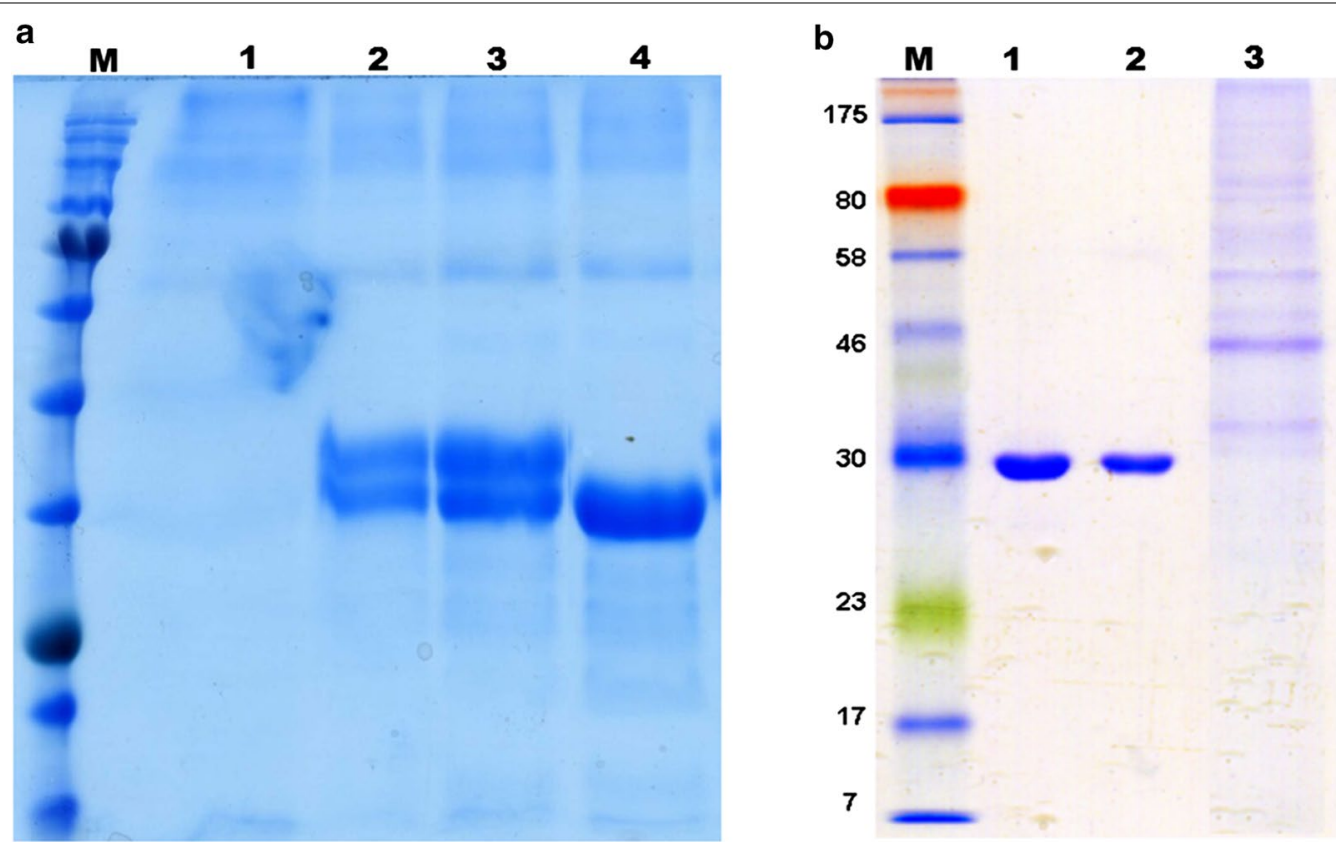

Fig. 3 SDS-PAGE analysis of the extracellular extract from recombinants; a lane 1 X-33/wild-type, lane 2X-33/pGAPZa + MCAP-5, lane 3 X-33/ pGAM1 + MCAP-3, lane 4 X-33/pGAM1 + MCAP-8, and $\mathbf{b}$ purified MCAP-3 digested with endoglycosidase (Endo H) lane 1 and purified MutMCAP-8 in lane 2

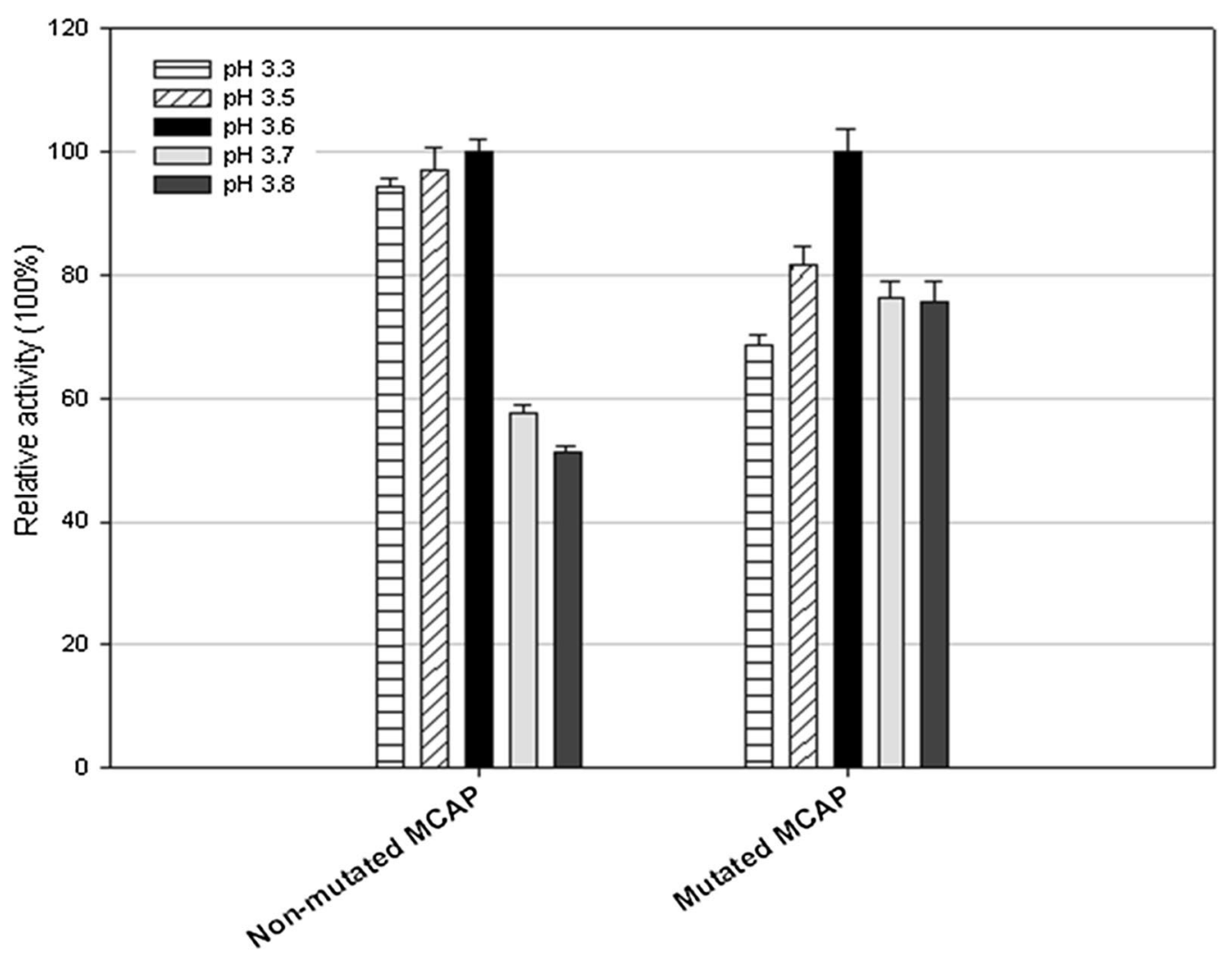

Fig. 4 Effect of pH on MCAP activity 

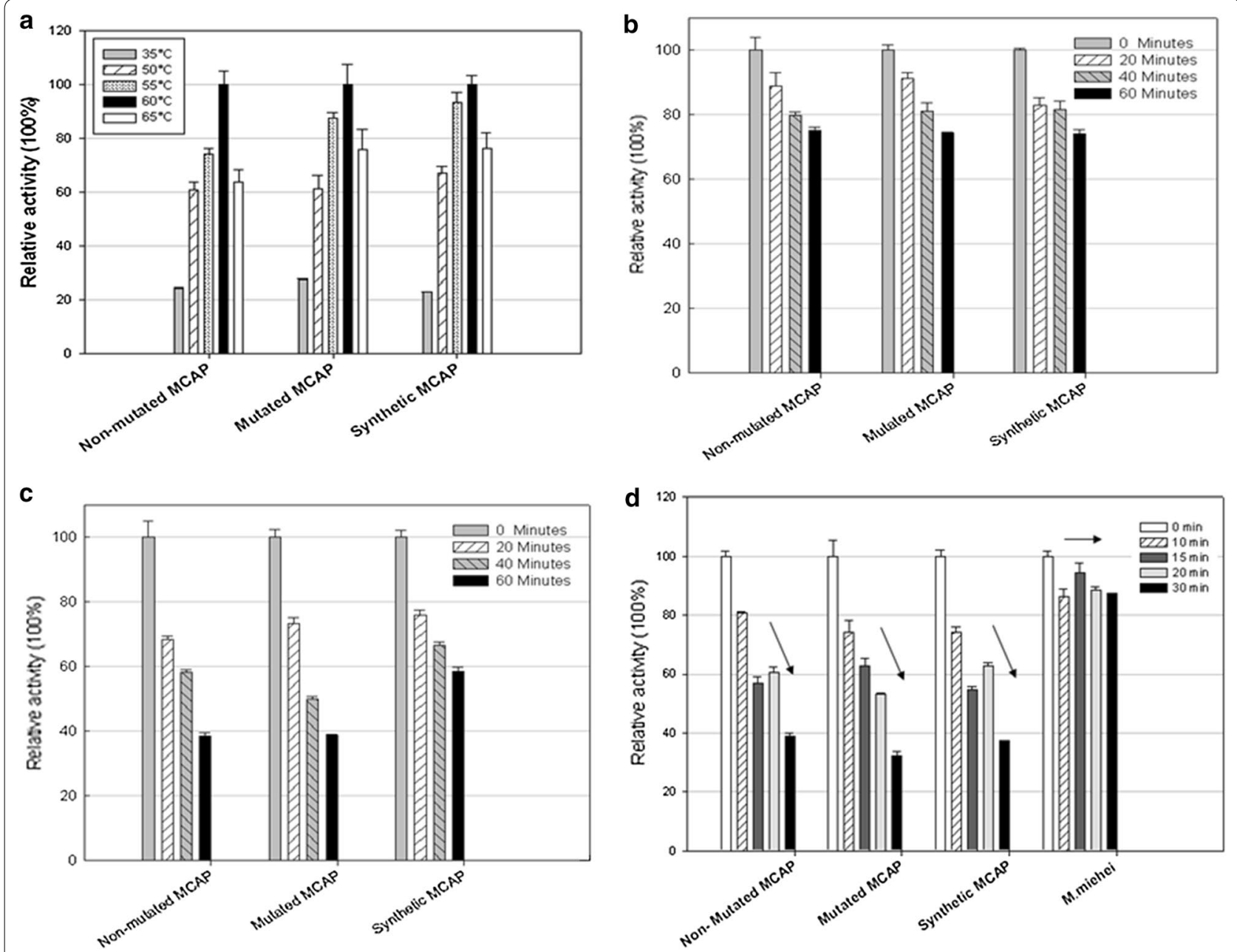

Fig. 5 Effect of; a Optimum temperature of MCAP, $\mathbf{b}$ Thermostability of the unpurified MCAP at $55^{\circ} \mathrm{C}, \mathbf{c}$ Thermostability of the unpurified MCAP at $60^{\circ} \mathrm{C}$, $\mathbf{d}$ Thermostability of the purified MCAP at $55^{\circ} \mathrm{C}$

effects should be studied by a further detailed structural analysis.

\section{Proteolytic activity}

Understanding proteolytic and milk clotting activity ratio is a vital criterion for the selection of a good milk coagulant, as it has been observed that the higher the ratio the more desirable the order of the action during cheese making. In this study, the proteolytic activity of the purified protein was determined at $\mathrm{pH} 5.8$, at $35^{\circ} \mathrm{C}$. The differences in proteolytic activity were recorded after 30 min of incubation ( $N, N$-dimethyl casein was used as the substrate). Table 4 shows the Milk-clotting activity (MCA), Proteolytic activity (PA) and the MCAP/PA ratio. This result indicates that glycosylation may have an effect
Table 4 Milk clotting and proteolytic activity of purified MCAP and its mutants

\begin{tabular}{|c|c|c|c|}
\hline Sample & MCA $\left(U \mu g^{-1}\right)$ & $\begin{array}{l}\text { Proteolytic } \\
\text { activity PA } \\
\left(U \mu g^{-1}\right)\end{array}$ & Ratio MCA/PA \\
\hline $\begin{array}{l}\text { MCAP-3 (non- } \\
\text { mutated) }\end{array}$ & 72 & $4.26 \pm 0.82$ & $17.35 \pm 3.75$ \\
\hline $\begin{array}{l}\text { SyMCAP-6 (syn- } \\
\text { thetic) }\end{array}$ & 137 & $7.02 \pm 0.28$ & $19.53 \pm 0.79$ \\
\hline $\begin{array}{r}\text { MutMCAP-8 } \\
\text { (mutated) }\end{array}$ & 204 & $13.56 \pm 1.47$ & $15.13 \pm 1.64$ \\
\hline M. mihei & 311 & $11.11 \pm 0.27$ & $28 \pm 0.68^{a}$ \\
\hline
\end{tabular}

Results shown are the means of three sets of experiments

a Data from Gama Salgado et al. (2013) 
on the milk clotting and proteolytic activity. Although the mutated protein showed the highest proteolytic activity no differences in the MCAP/PA ratio were observed in relation to the non-mutated protein. From the results, we can say that nonglycosylated enzymes could also be a good alternative to the existing preparations for cheese manufacturing.

\section{Discussion}

To investigate the expression of MCAP gene in P. pastoris, several plasmid constructions harbouring intact or partial $M C A P$ gene sequence were generated. Initially, a novel $M$. circinelloides aspartic protease gene (MCAP) was cloned into pGAPZ $\alpha A$, a commercial plasmid (Invitrogen, Darmstadt, Germany) that expresses protein using a constitutive GAP promoter with a secretion signal sequence (the $S$. cerevisiae $\alpha-M F$ pre-pro signal sequence) for secreting needed protein in the culture media (Gama Salgado et al. 2013). No MCAP was secreted when MCAP was produced without the prepropeptide sequence, peptide important for correct folding during secretion in zymogens (Mellor et al. 1983; Gray et al. 1986; Tonouchi et al. 1986; Horiuchi et al. 1988; Hiramatsu et al. 1989), nor when the secretion signal ( $\alpha-M F)$ of S. cerevisiae (Brake et al. 1984) followed by mcSP was used in the expression system (Table 2). This phenomenon can be called incompatibility of SP sequence. Furthermore, the strain carrying the intact $M C A P$ gene (with intron sequence) was not able to produce MCAP. This might be due to $P$. pastoris inability to cleave the MCAP gene intron sequence, as it was also observed by Horiuchi et al. in $S$. cerevisiae when the $R$. niveus aspartic proteinase containing an intron sequence was used (Horiuchi et al. 1988). On the other hand, when the intron of the MCAP gene was removed, the recombinant strain secreted MCAP into the medium at a concentration exceeding $110 \mathrm{mg} \mathrm{L}^{-1}\left(249 \mathrm{MCU} \mathrm{mL}^{-1}\right)$ a level not comparable to the MCAP expressed in the fungus $M$. circinelloides $\left(800-1000 \mathrm{MCU} \mathrm{mL}^{-1}\right)$. For efficient secretion of MCAP in P. pastoris, the MCAP gene sub-cloned into a new expression vector pGAM1 (pGAM1 without the $S$. cerevisiae $\alpha-M F$ pre-pro signal sequence) and the level of protein expression between mcSP and $\alpha-\mathrm{MF}$ was compared. When using the mcSP, the aspartic proteinase was secreted in active form into the culture medium at a concentration exceeding $250 \mathrm{mg} \mathrm{L}^{-1}\left(1000 \mathrm{MCU} \mathrm{mL}^{-1}\right)$ indicating a 1.5-fold increase in the secretion of MCAP by $P$. pastoris as compared to when the $\alpha$-MF secretion signal of $S$. cerevisiae was used. The reason for increased secretion could be that the processing of $\alpha$-MF require three steps; removal of peptide signal, Kex2 endopeptidases cleavage and repeats of the Glu-Ala cleavage), while the processing of mcSP need only one, the removal of the peptide signal and this provides an advantage over the existing commercial expression vector. Furthermore, the number of genes in $P$. pastoris were analyzed by the real-time PCR-based method and no differences were observed among the strains.

Additionally, when the original MCAP gene was adapted to the optimal codon usage of $P$. pastoris, the production of heterologous MCAP was increased three folds. The synthetic gene is $78 \%$ identical (nucleotide sequence level) to the original and the observed increase in production of several other recombinant proteins in $P$. pastoris using codon optimization has also been reported in the literature (Sinclair and Choy 2002; Xiong et al. 2005; Gao et al. 2013).

This study also shows that MCAP is N-glycosylated at Asn331 when produced in P. pastoris, and no much difference was observed on the effect of the $\mathrm{N}$-glycosylation on the stability and activity of the protein, as the proteolytic (PA) and milk clotting activity (MCA) ratios were similar between MCAP-3 and mutMCAP-8 (Table 4). Rao et al. (2011) reported that most aspartic proteinases show maximal activity between $\mathrm{pH} 3$ and 4, and their molecular masses range from 30 to $45 \mathrm{kDa}$, though some can be higher.

With the data obtained, non-glycosylated protein can also be used as a better candidate for cheese production. Literature data have shown that the sequon Asn-Xaa-Thr rather than Asn-Xaa-Ser (Daly and Hearn 2005) is readily glycosylation as we have already observed in the data obtained in this study. The position of sequon in relation to the protein $\mathrm{C}$-terminus was also labelled as a decisive factor for extended glycosylation since the sequence of the consecutive amino acids which are situated close to the $\mathrm{N}$-terminus have been noted to be prone to glycosylation than those closer to the C-terminus (Shelikoff et al. 1996). Experimental results by Gavel and Gunnar von Heijne (1990) also indicate that the $\mathrm{N}$-glycosylation site does not always lead to glycosylation, especially when the sites are at the C-termini of proteins. Remarkably, the MCAP comprises the consecutive amino acids situated near the C-terminus (Asn331 in the MCAP of 394 amino acid residues). Therefore, $P$. pastoris is capable of excreting two types of MCAPs. Additional data obtained by Shakin-Eshleman et al. (Mellquist et al. 1998), propose that a specific amino acid at the $X$ location of an Asn- $X$ Ser sequon is vital for $N$-linked Core-Glycosylation Efficiency (CGE). It was observed that the replacement of the amino acid $\mathrm{X}$ with Phe, improved the efficiency of core glycosylation (mean CGE $=70 \%$ ) and in our case, the protein contains Phenylalanine at the $\mathrm{X}$ position of the sequon. The results indicate that the intensity of the band showing glycosylated recombinant protein was more intense than the recombinant non-glycosylated one. 
Also, we observed that glycosylation had no significant effect on the thermostability of the purified protein, as both glycosylated and unglycosylated proteins revealing similar clotting activity and proteolytic activity ratios. In this study, $83 \%$ of the residual activity of commercial rennet from $R$. miehei after exposure to heat for $30 \mathrm{~min}$ was observed (Fig. 5d), while that of purified MCAP was less than $40 \%$. The fact that the protein has low thermal stability and relatively high milk clotting activity to proteolytic activity ratio, the enzyme(s) can be a better candidate for commercial rennet preparations for the cheese industry.

The $P$. pastoris expression system used in this study resulting in functional secretion of the $M$. circinelloides aspartic proteinase and its mutant forms can further be used in the production of the enzyme in large scale.

It was also found that the native signal peptide $(\mathrm{mcSP})$ was effective for protein secretion in yeast cells and could be used as an alternative to the alpha-factor SP mainly used in yeast protein secretion. Available data (von Heijne 1983) has shown that sequences leaders possess markedly three regions (n-region, h-region and c-region), which consists of specific amino acids that make up the primary structure of the protein. The n-region varies from one to five amino acids in length from the initiator methionine to the region- $h$ and has a positive charge, while the region-h is a central hydrophobic core varies from 8 to 12 residues (Nielsen and Krogh 1998; Laforet and Kendall 1991). In relation to the region c, it is known that this region is polar containing 3 to 7 amino acids but most of the residues are not charged. It should be noted that the region $\mathrm{c}$ is involved in the recognition and cleavage by signal peptidase. Particularly, the amino acids at the location -3 and -1 in relation to the cleavage site, plays an important role in the correct signal peptide cleavage (von Heijne 1983). Furthermore, it has been shown that the characteristics of the mature amino terminus should be involved in determining the exact cleavage site (Laforet and Kendall 1991). Taking this prediction, the mcSP sequence was searched against the GenBank database for non-redundant protein using the BLASTP 2.2.27 program. Interestingly, the results obtained indicated that mcSP has several amino acid residues present in aspartic proteinases produced by various fungi (Fig. 1). We also found that the first four amino acids from the $\mathrm{N}$-terminal sequence of aspartic proteinases were conserved in at least three residues. In addition, we found that some of the $\mathrm{N}$-terminal residues of mature MCAP at positions +1 to +5 to the relative cleave site of $\mathrm{mcSP}$ are present in the same position of a secreted protein native to $P$. pastoris. Based on this result, we analyzed the $\alpha$-MF of $S$. cerevisiae including some heterologous signal peptides, which have shown a proper functioning in $P$. pastoris. As an illustration, we compared these sequences including the first 10 amino acids just after the cleavage site to 54 native signal peptide sequences of $P$. pastoris, which were recently predicted (De Schutter et al. 2009), and some residues of the $\alpha$-MF pro-sequence (Waters et al. 1988; $\mathrm{He}$ et al. 2012) matched with $\mathrm{N}$-terminal amino acids of a mature protein of $P$. pastoris. In addition, we observed similar results with the glucoamylase (Chen et al. 2007), pectate lyase B (Guo et al. 1995), laccase (Liu et al. 2003), alpha-1-antitrypsin (Arjmand et al. 2013), urine protein complex (Ferrari et al. 1997), acetylcholinesterase (Morel and Massoulie 1997) and alpha amylase signal peptide ( $\mathrm{Li}$ et al. 2011).

In a comparative analysis, only part of the secretome predicted to P. pastoris was used (De Schutter et al. 2009). Possibly some of the sequences analyzed might match better with other signal peptides of the yeast. These results presented here can perhaps contribute to the improvement of heterologous protein secretion.

This study provides guidance for the enhanced enzyme production focusing on the utilizing the native $\mathrm{SP}$ and also the N-linked glycosylated modification that can help meet the imminent needs of industries and can offer an excellent biocatalyst for the application in other biotechnological industries.

Our next tasks will be to quantitatively analyze gene expression and evaluate the effectiveness of utilizing mcSP in various protein secretion.

\section{Additional file}

Additional file 1: Table S1. The Nucleotide and deduced the amino acid sequence of MCAP protein. The deduced amino acid sequence is shown under the nucleotide sequence. The arrow indicates the signal peptide cleavage site and lowercase letters indicate nucleotides in the intron sequence. The catalytic Asp residues (motifs DTGS and DTGT) are boxed. The N-glycosylation site is single underlined. Asterisk indicates the position of the stop codon (TAA).

\section{Abbreviations}

MCAP: Mucor circinelloides aspartic protease; mcSP-MCAP: signal peptide Mucor circinelloides aspartic protease; MCU: milk clotting units.

\section{Authors' contributions}

MK, JAGS and MFL have designed the work. MK, JAGS carried out the experiment. MK, JAGS and MFL analyzed the data and contributed to the statistical analysis. MK, JAGS and MFL wrote the manuscript and reviewed the manuscript critically. All authors read and approved the final manuscript.

\section{Acknowledgements}

The authors would like to thank Jacobs University and the Downstream Bioprocessing Laboratory for the support.

Competing interests

The authors declare that they have no competing interests. 


\section{Availability of data and materials}

All data are fully available without restriction.

\section{Consent for publication}

This manuscript does not contain any individual person's data.

\section{Ethics approval and consent to participate}

No animal or human subjects were used in this work.

\section{Funding}

This research including the design of the study, analysis, and interpretation of data, as while as writing the manuscript was all funded by from Project PGSYSEXCHANGE EU-PIRSES\#269211, ERA-Net Euro TransBio-3, PGYSYS, INTENSO PROJECT, European Union Seventh Framework Programme (FP7/2013-2017) under Grant Agreement No. 312004 and Project NANOZYME, BMBF - EuroTransBio-9 (ETB-9) No. 031B0017C, and Jacobs University Bremen.

\section{Publisher's Note}

Springer Nature remains neutral with regard to jurisdictional claims in published maps and institutional affiliations.

\section{Received: 4 July 2018 Accepted: 26 September 2018}

Published online: 01 October 2018

\section{References}

Aikawa J, Yamashita T, Nishiyama M, Horinouchi S, Beppu T (1990) Effects of glycosylation on the secretion and enzyme activity of Mucor rennin, an aspartic proteinase of Mucor pusillus, produced by recombinant yeast. J Biol Chem 265:13955-13959

Arima K, Yu J, Iwasaki S, Tamura G (1968) Milk-clotting Enzyme from Microorganisms: V. Purification and Crystallization of Mucor Rennin from Mucor pusillus var. Lindt. Appl Microbiol 16:1727-1733

Arjmand S, Lotfi AS, Shamsara M, Mowla SJ (2013) Elevating the expression level of biologically active recombinant human alpha 1-antitrypsin in Pichia pastoris. Electron J Biotechnol 16:4

Blobel G (2000) Protein targeting (Nobel lecture). ChemBioChem 1:87-102

Bradford MM (1976) A rapid and sensitive method for the quantitation of microgram quantities of protein utilizing the principle of protein-dye binding. Anal Biochem 72:248-254

Brake AJ, Merryweather JP, Coit DG, Heberlein UA, Masiarz FR, Mullenbach GT, Urdea MS, Valenzuela P, Barr PJ (1984) Alpha-factor-directed synthesis and secretion of mature foreign proteins in Saccharomyces cerevisiae. Proc Natl Acad Sci USA 81(15):4642-4646

Celebi M, Topuzogullari M, Kuzu H (2016) Thermal destabilization of Rhizomucor miehei rennet with aldehyde dextran sulfate: purification, bioconjugation and milk-clotting activities. Appl Biochem Biotechnol 180:261-273

Chen J, Zhang YQ, Zhao CQ, Li AN, Zhou QX, Li DC (2007) Cloning of a gene encoding thermostable glucoamylase from Chaetomium thermophilum and its expression in Pichia pastoris. J Appl Microbiol 103:2277-2284

Daly R, Hearn MT (2005) Expression of heterologous proteins in Pichia pastoris: a useful experimental tool in protein engineering and production. J Mol Recognit 18:119-138

De Schutter K, Lin YC, Tiels P, Van Hecke A, Glinka S, Weber-Lehmann J, Rouzé P, Van de Peer Y, Callewaert N (2009) Genome sequence of the recombinant protein production host Pichia pastoris. Nat Biotechnol 27:561

Dietzsch C, Spadiut O, Herwig C (2011) A fast approach to determine a fed batch feeding profile for recombinant Pichia pastoris strains. Microb Cell Fact 10:1475-2859

El-Baky HA, Linke D, Nimtz M, Berger RG (2011) PsoP1, a milk-clotting aspartic peptidase from the basidiomycete fungus Piptoporus soloniensis. J Agric Food Chem 59:10311-10316

Fan T, Wang J, Yuan W, Zhong Q, Shi Y, Cong R (2010) Purification and characterization of hatching enzyme from brine shrimp Artemia salina. Acta Biochim Biophys Sin 42:165-171

Fernandez-Lahore HM, Auday RM, Fraile ER, de Jimenez Biscoglio, Bonino M, Pirpignani L, Machalinski C, Cascone O (1999) Purification and characterization of an acid proteinase from mesophilic Mucor sp. solid-state cultures. J Pept Res 53:599-605
Ferrari E, Lodi T, Sorbi RT, Tirindelli R, Cavaggioni A, Spisni A (1997) Expression of a lipocalin in Pichia pastoris: secretion, purification and binding activity of a recombinant mouse major urinary protein. FEBS Lett 401:73-77

Fitchette-Lainé AC, Denmat LA, Lerouge P, Faye L (1998) Analysis of N- and O-Glycosylation of Plant Proteins. In: Cunningham C, Porter AJR (eds) Recombinant Proteins from Plants: Production and Isolation of Clinically Useful Compounds. Humana Press, Totowa, pp 271-290

Gama Salgado JA, Kangwa M, Fernandez-Lahore M (2013) Cloning and expression of an active aspartic proteinase from Mucor circinelloides in Pichia pastoris. BMC Microbiol 13:250

Gao L, Cai M, Shen W, Xiao S, Zhou X, Zhang Y (2013) Engineered fungal polyketide biosynthesis in Pichia pastoris: a potential excellent host for polyketide production. Microb Cell Fact 12:1475-2859

Gavel Y, von Heijne G (1990) Sequence differences between glycosylated and non-glycosylated Asn-X-Thr/Ser acceptor sites: implications for protein engineering. Protein Eng 3:433-442

Gray GL, Hayenga K, Cullen D, Wilson LJ, Norton S (1986) Primary structure of Mucor miehei aspartyl protease: evidence for a zymogen intermediate. Gene 48:41-53

Guo W, Gonzalez-Candelas L, Kolattukudy PE (1995) Cloning of a novel constitutively expressed pectate lyase gene pelB from Fusarium solanif. sp. pisi (Nectria haematococca, mating type $\mathrm{VI}$ ) and characterization of the gene product expressed in Pichia pastoris. J Bacteriol 177:7070-7077

Hang F, Liu P, Wang Q, Han J, Wu Z, Gao C, Lui Z, Zhang H, Chen W (2016) High milk-clotting activity expressed by the newly isolated Paenibacillus spp. strain BD3526. Molecules 21:73

He Z, Huang Y, Qin Y, Liu Z, Mo D, Cong P, Chen Y (2012) Comparison of alpha-factor preprosequence and a classical mammalian signal peptide for secretion of recombinant xylanase xynB from yeast Pichia pastoris. J Microbiol Biotechnol 22:479-483

Hiramatsu R, Aikawa J, Horinouchi S, Beppu T (1989) Secretion by yeast of the zymogen form of mucor rennin, an aspartic proteinase of Mucor pusillus, and its conversion to the mature form. J Biol Chem 264:16862-16866

Horiuchi H, Yanai K, Okazaki T, Takagi M, Yano K (1988) Isolation and sequencing of a genomic clone encoding aspartic proteinase of Rhizopus niveus. J Bacteriol 170:272-278

Hsiao NW, Chen Y, Kuan YC, Lee YC, Lee SK, Chan HH, Kao CH (2014) Purification and characterization of an aspartic protease from the Rhizopus oryzae protease extract, Peptidase R. Electron J Biotechnol 17:89-94

Jacob M, Jaros D, Rohm H (2011) Recent advances in milk clotting enzymes. Int J Dairy Technol 64:14-33

Kethireddipalli P, Hill AR (2015) Rennet coagulation and cheesemaking properties of thermally processed milk: overview and recent developments. J Agric Food Chem 63:9389-9403

Kumar A, Grover S, Sharma J, Batish VK (2010) Chymosin and other milk coagulants: sources and biotechnological interventions. Crit Rev Biotechnol $30: 243-258$

Laforet GA, Kendall DA (1991) Functional limits of conformation, hydrophobicity, and steric constraints in prokaryotic signal peptide cleavage regions. Wild type transport by a simple polymeric signal sequence. J Biol Chem 266:1326-1334

Laukens B, De Wachter C, Callewaert N (2015) Engineering the Pichia pastoris $\mathrm{N}$-glycosylation pathway using the glycoswitch technology. Methods Mol Biol 1321:103-122

Li S, Sing S, Wang Z (2011) Improved expression of Rhizopus oryzae alphaamylase in the methylotrophic yeast Pichia pastoris. Protein Expr Purif 79:142-148

Liu W, Chao Y, Liu S, Bao H, Qian S (2003) Molecular cloning and characterization of a laccase gene from the basidiomycete Fome lignosus and expression in Pichia pastoris. Appl Microbiol Biotechnol 63:174-181

Mandujano-González V, Téllez-Jurado A, Anducho-Reyes MA, Arana-Cuenca A, Mercado-Flores Y (2016) Purification and characterization of the extracellular aspartyl protease APSm1 from the phytopathogen fungus Stenocarpella maydis. Protein Exp Purif 117:1-5

Mellor J, Dobson MJ, Roberts NA, Tuite MF, Emtage JS, White S, Lowe PA, Patel T, Kingsman AJ, Kingsman SM (1983) Efficient synthesis of enzymatically active calf chymosin in Sacchaomyces cerevisiae. Gene 24:1-14

Mellquist JL, Kasturi L, Spitalnik SL, Shakin-Eshleman SH (1998) The amino acid following an asn-X-Ser/Thr sequon is an important determinant of $\mathrm{N}$-linked core glycosylation efficiency. Biochemistry 37:6833-6837 
Morel N, Massoulie J (1997) Expression and processing of vertebrate acetylcholinesterase in the yeast Pichia pastoris. Biochem J 328:121-129

Nasr AIAM, Mohamed Ahmed IA, Hamid OIA (2016) Characterization of partially purified milk-clotting enzyme from sunflower (Helianthus annuus) seeds. Food Sci Nutr 4:733-741

Neelima Sharma R, Rajput YS, Mann B (2013) Chemical and functional properties of glycomacropeptide (GMP) and its role in the detection of cheese whey adulteration in milk: a review. Dairy Sci Technol 93:21-43

Nielsen H, Krogh A (1998) Prediction of signal peptides and signal anchors by a hidden Markov model. Proc Int Conf Intell Syst Mol Biol 6:122-130

Ottesen M, Rickert W (1970) The isolation and partial characterization of an acid protease produced by Mucor miehei. C R Trav Lab Carlsberg 37:301-325

Rao S, Mizutani O, Hirano T, Masaki K, lefuji H (2011) Purification and characterization of a novel aspartic protease from basidiomycetous yeast Cryptococcus sp. S-2. J Biosci Bioeng 112:441-446

Rickert WS, McBride-Warren PA (1977) Structural and functional determinants of Mucor miehei protease VI. Inactivation of the enzyme by diazoacetyl norleucine methyl esters, pepstatin and 1,2-epoxy-30(p-nitro-phenyoxy) propane. Biochim Biophys Acta 480:262-274

Salehi M, Aghamaali MR, Sajedi RH, Asghari SM, Jorjani E (2017) Purification and characterization of a milk-clotting aspartic protease from Withania coagulans fruit. Int J Biol Macromol 98:847-854

Shelikoff M, Sinskey AJ, Stephanopoulos G (1996) A modeling framework for the study of protein glycosylation. Biotechnol Bioeng 50:73-90

Sinclair G, Choy FY (2002) Synonymous codon usage bias and the expression of human glucocerebrosidase in the methylotrophic yeast, Pichia pastoris. Protein Expr Purif 26(1):96-105

Soltani M, Sahingil D, Gokce Y, Hayaloglu AA (2016) Changes in volatile composition and sensory properties of Iranian ultrafiltered white cheese as affected by blends of Rhizomucor miehei protease or camel chymosin. J Dairy Sci 99:7744-7754

Spadiut O, Herwig C (2014) Dynamics in bioprocess development for Pichia pastoris. Bioengineered 5:401-404
Spiro RG (2002) Protein glycosylation: nature, distribution, enzymatic formation, and disease implications of glycopeptide bonds. Glycobiology 12:43R-56R

Tonouchi N, Shoun H, Uozumi T, Beppu T (1986) Cloning and sequencing of a gene for Mucor rennin, an aspartate protease from Mucor pusillus. Nucleic Acids Res 14:7557-7568

von Heijne G (1983) Patterns of amino acids near signal-sequence cleavage sites. Eur J Biochem 133:17-21

Walsh G, Jefferis R (2006) Post-translational modifications in the context of therapeutic proteins. Nat Biotechnol 24:1241-1252

Waters MG, Evans EA, Blobel G (1988) Prepro-alpha-factor has a cleavable signal sequence. J Biol Chem 263:6209-6214

Xiong AS, Yao QH, Peng RH, Han PL, Cheng ZM, LiY (2005) High level expression of a recombinant acid phytase gene in Pichia pastoris. J Appl Microbiol 98:418-428

Yamashita T, Higashi S, Higashi T, Machida H, Iwasaki S, Nishiyama M, Beppu T (1994) Mutation of a fungal aspartic proteinase, Mucor pusillus rennin, to decrease thermostability for use as a milk coagulant. J Biotechnol 32:17-28

Yang M, Yu XW, Zheng H, Sha C, Zhao C, Qian M, Xu Y (2015) Role of N-linked glycosylation in the secretion and enzymatic properties of Rhizopus chinensis lipase expressed in Pichia pastoris. Microb Cell Fact 14:015-0225

Yegin S, Dekker P (2013) Progress in the field of aspartic proteinases in cheese manufacturing: structures, functions, catalytic mechanism, inhibition, and engineering. Dairy Sci Technol 93:565-594

Zhang J, Sun Y, Li Z, Luo Q, Li T, Wang T (2015) Structure-based design of Mucor pusillus pepsin for the improved ratio of clotting activity/proteolytic activity in cheese manufacture. Protein Pept Lett 22:660-667

\section{Submit your manuscript to a SpringerOpen ${ }^{\odot}$ journal and benefit from:}

- Convenient online submission

- Rigorous peer review

- Open access: articles freely available online

- High visibility within the field

- Retaining the copyright to your article

Submit your next manuscript at $\boldsymbol{\nabla}$ springeropen.com 